\title{
Work sampling for the production development: A case study of a supplier in European automotive industry
}

\author{
Martinec, T. ${ }^{a}$, Škec, S. ${ }^{a}$, Savšek, T. ${ }^{b}$, Perišić, M.M. ${ }^{a}$ \\ a University of Zagreb, Faculty of Mechanical Engineering and Naval Architecture, Zagreb, Croatia \\ ${ }^{b}$ TPV d.d., Novo Mesto, Slovenia
}

\section{A B S T R A C T}

Effective development of production processes within modern engineering projects requires project management to take into consideration the sociotechnical project aspects, such as insights into individual and team work, including how much time team members spend on different activities, how they communicate, within what context and in what manner. The paper reports on a self-reporting work sampling approach developed and tailored for the production development and the application of the approach in an automotive industry supplier company. A case study was conducted in a Tier 1 development and manufacturing supplier for the automotive industry in EU. Although the approach requires a significant amount of preparation efforts to configure the tools and reduce participants self-reporting bias, it is less intrusive during data collection as it does not require the presence of researchers. Results provide insights into team members' work type engagement and how their activity was coupled with the context, the manner and the nature of information transaction utilized. Project managers can use these insights to tailor workloads and modify team composition to improve collaboration, coordination and information exchange.
\end{abstract}

\section{ARTICLE INFO}

Keywords:

Automotive industry

Production development

Project management

Teamwork

Work sampling

*Corresponding author: tomislav.martinec@fsb.hr (Martinec, T.)

Article history:

Received 24 February 2017

Revised 23 October 2017

Accepted 26 October 2017

\section{References}

[1] Bellgran, M., Säfsten, K. (2010). Production development, design and operation of production systems, SpringerVerlag London, doi: 10.1007/978-1-84882-495-9.

[2] Fogliatto, F.S., da Silveira, G.J.C., Borenstein, D. (2012). The mass customization decade: An updated review of the literature, International Journal of Production Economics. Vol. 138, No. 1, 14-25, doi: 10.1016/i.ijpe.2012.03.002.

[3] Ciravegna, L., Romano, P., Pilkington, A. (2013). Outsourcing practices in automotive supply networks: An exploratory study of full service vehicle suppliers, International Journal of Production Research, Vol. 51, No. 8, 2478-2490, doi: 10.1080/00207543.2012.746797.

[4] Sharafi, A., Wolfenstetter, T., Wolf, P., Krcmar, H. (2010). Comparing product development models to identify process coverage and current gaps: A literature review, In: Proc 2010 IEEE International Conference on Industrial Engineering and Engineering Management, Macao, China, 1732-1736, doi: 10.1109/IEEM.2010.5674575.

[5] Naveh, E. (2005). The effect of integrated product development on efficiency and innovation, International Journal of Production Research, Vol. 43, No. 13, 2789-2808, doi: 10.1080/00207540500031873.

[6] Koren, R., Palčič, I. (2015). The impact of technical and organisational innovation concepts on product characteristics, Advances in Production Engineering \& Management, Vol. 10, No. 1, 27-39, doi: 10.14743/apem2015.1.190.

[7] Thamhain, H. (2013). Managing risks in complex projects, Project Management Journal, Vol. 44, No. 2, 20-35, doi: $10.1002 / \mathrm{pmj} .21325$.

[8] Cicmil, S., Williams, T., Thomas, J., Hodgson, D. (2006). Rethinking Project Management; Researching the actuality of projects, International Journal of Project Management, Vol. 24, No. 8, 675-686, doi: 10.1016/j.ijproman. 2006.08.006. 
[9] Thoring, K., Mueller, R.M., Badke-Schaub, P. (2015). Technology-supported design research, In: Proceedings of the 20th International Conference on Engineering Design (ICED 15), Vol 11: Human Behaviour in Design, Design Education, Milan, Italy, 31-40.

[11] Matias, A.C. (2001). Work measurement: principles and techniques, In: Salvendy, G. (ed.), Handbook of industrial engineering: technology and operations management: Third edition, John Wiley \& Sons, Hoboken, New York, USA, 1409-1462, doi: 10.1002/9780470172339.ch54.

[10] Robinson, M.A. (2010). Work sampling: Methodological advances and new applications, Human Factors and Ergonomics in Manufacturing \& Service Industries, Vol. 20, No. 1, 42-60, doi: 10.1002/hfm.20186.

[12] Kušar, J., Rihar, L., Gorenc, S., Starbek, M. (2012). Teamwork in the simultaneous product realisation, Strojniški vestnik - Journal of Mechanical Engineering, Vol. 58, No. 9, 534-544, doi: 10.5545/sv-jme.2012.420.

[13] Rösiö, C., Bruch, J., Johansson, A. (2015). Early production involvement in new product development, In: POMS 26th Annual Conference, Washington DC, USA.

[14] Lee, J.Y., Swink, M., Pandejpong, T. (2017). Team diversity and manufacturing process innovation performance: The moderating role of technology maturity, International Journal of Production Research, Vol. 55, No. 17, 49124930, doi: 10.1080/00207543.2016.1272765.

[15] Feng, B., Jiang, Z.-Z., Fan, Z.-P., Fu, N. (2010). A method for member selection of cross-functional teams using the individual and collaborative performances, European Journal of Operational Research, Vol. 203, No. 3, 652-661, doi: 10.1016/j.ejor.2009.08.017.

[16] Badke-Schaub, P. (1999). Group effectiveness in design practice: Analysis and training by a critical-situationapproach, Psychologische Beiträge, Vol. 41, No. 3, 338-355.

[17] Pavković, N., Štorga, M., Bojčetić, N., Marjanović, D. (2013). Facilitating design communication through engineering information traceability, Artificial Intelligence for Engineering Design, Analysis and Manufacturing, Vol. 27, No. 2, 105-119, doi: 10.1017/S0890060413000012.

[18] Robinson, M.A. (2012). How design engineers spend their time: Job content and task satisfaction, Design Studies, Vol. 33, No. 4, 391-425, doi: 10.1016/j.destud.2012.03.002

[19] Škec, S., Štorga, M., Tečec Ribarić, Z. (2016). Work sampling of product development activities, Tehnički vjesnik Technical Gazette, Vol. 23, No. 6, 1547-1554, doi: 10.17559/tv-20150606151030.

[20] Kirwan, B., Ainsworth, L.K. (1992). A guide to task analysis: The task analysis working group, CRC Press, London, UK, doi: $10.1201 / \mathrm{b} 16826$.

[21] Sim, S.K., Duffy, A.H.B. (2003). Towards an ontology of generic engineering design activities, Research in Engineering Design, Vol. 14, No. 4, 200-223, doi: 10.1007/s00163-003-0037-1.

[22] Ahmed, S., Storga, M. (2009). Merged ontology for engineering design: Contrasting empirical and theoretical approaches to develop engineering ontologies, Artificial Intelligence for Engineering Design, Analysis and Manufacturing, Vol. 23, No. 4, 391-407, doi: 10.1017/s0890060409000146.

[23] Allard, S., Levine, K.J., Tenopir, C. (2009). Design engineers and technical professionals at work: Observing information usage in the workplace, Journal of the American Society for Information Science and Technology, Vol. 60, No. 3, 443-454, doi: 10.1002/asi.21004.

[24] McAlpine, H., Cash, P., Storton, A., Culley, S. (2011). A technology selection process for the optimal capture of design information, In: Proceedings of the 3rd International Conference on Research into Design Engineering (ICORD 11), Bangalore, India, 11-18.

[25] Cash, P. (2012). Characterising the relationship between practice and laboratory-based studies of designers for critical design situations, Ph.D. thesis, University of Bath, UK.

[26] Škec, S., Štorga, M., Tečec Ribarić, Z., Marjanović, D. (2015). Work sampling approach for measuring intellectual capital elements in product development context, In: Proceedings of the 20th International Conference on Engineering Design (ICED 15) Vol 3: Organisation and Management, Milan, Italy, 457-466.

[27] Surbier, L., Alpan, G., Blanco, E. (2014). A comparative study on production ramp-up: State-of-the-art and new challenges, Production Planning \& Control, The Management of Operations, Vol. 25, No. 15, 1264-1286, doi: $10.1080 / 09537287.2013 .817624$.

[28] Pape, E.S. (1988). Work sampling, In: Gael, S. (ed.), The Job Analysis Handbook for Business, Industry, and Government, John Wiley \& Sons, New York, USA, 518-535.

[29] Webster, J., Higgs, P. (1973). An analysis of drawing office activities, Building Services Engineer, Vol. 40, $246-257$.

[30] Lowe, A., McMahon, C., Culley, S. (2004). Information access, storage and use by engineering designers, part 1, The Journal of the Institution of Engineering Designers, Vol. 30, No. 2, 30-32.

[31] Marsh, J.R. (1997). The capture and utilisation of experience in engineering design, Ph.D. thesis, University of Cambridge, UK.

[32] Gopsill, J., Jones, S., Snider, C., Shi, L., McMahon, C.A., Hicks, B.J. (2014). Understanding the engineering design process through the evolution of engineering digital objects, In: Proceedings of the 13th International Design Conference (DESIGN 2014), Dubrovnik, Croatia, 1773-1784.

[33] Wasiak, J.O.A. (2010). Content based approach for investigating the role and use of e-mail in engineering design projects, Ph.D. thesis, University of Bath, UK.

[34] Donaldson, S.I., Grant-Vallone, E.J. (2002). Understanding self-report bias in organizational behavior research, Journal of Business and Psychology, Vol. 17, No. 2, 245-260, doi: 10.1023/A:1019637632584.

[35] Banduka, N., Veža, I., Bilić, B. (2016). An integrated lean approach to process failure mode and effect analysis (PFMEA): A case study from automotive industry, Advances in Production Engineering \& Management, Vol. 11, No. 4, 355-365, doi: 10.14743/apem2016.4.233. 


\section{APEM}

\title{
Vzorčenje dela za razvoj proizvodnje: študija primera dobavitelja v evropski avtomobilski industriji
}

\author{
Martinec, T. ${ }^{a}$, Škec, S. ${ }^{a}$, Savšek, T. ${ }^{b}$, Perišić, M.M. ${ }^{a}$ \\ ${ }^{a}$ University of Zagreb, Faculty of Mechanical Engineering and Naval Architecture, Zagreb, Croatia \\ ${ }^{b}$ TPV d.d., Novo Mesto, Slovenia
}

\section{POVZETEK}

Učinkovit razvoj proizvodnih procesov v sodobnih inženirskih projektih zahteva, da vodstvo projektov upošteva družbeno-tehnične aspekte projekta, kot so vpogled v individualno in skupinsko delo, vključno s tem, koliko časa člani ekipe porabijo za različne dejavnosti, kako komunicirajo, v katerem kontekstu in na kakšen način. Prispevek poroča o pristopu samostojnega poročanja o vzorčenju dela, ki je bil razvit in prilagojen razvoju proizvodnje ter uporabi v podjetju, dobavitelju avtomobilske industrije. Študija primera je bila izvedena $\mathrm{v}$ razvojnem in proizvodnem podjetju, dobavitelju prvega reda za avtomobilsko industrijo v EU. Čeprav pristop zahteva večjo prizadevnost za pripravo orodij in zmanjšanje pristranskosti poročanja udeležencev, je med zbiranjem podatkov manj vsiljiv, saj ne zahteva prisotnosti raziskovalcev. Rezultati zagotavljajo vpogled $\mathrm{v}$ sodelovanje članov ekipe, kako je njihova dejavnost vključena v skupni kontekst ter način in naravo uporabljene informacijske transakcije. Vodje projektov lahko uporabijo te vpoglede za prilagoditev delovne obremenitve in spreminjanje sestave ekipe za izboljšanje sodelovanja, koordinacijo in izmenjavo informacij.

\section{PODATKI O ČLANKU}

Ključne besede: Avtomobilska industrija

Razvoj proizvodnje

Vodenje projektov

Skupinsko delo

Vzorčenje dela

*Kontaktna oseba: tomislav.martinec@fsb.hr (Martinec, T.)

Zgodovina članka:

Prejet 24. februarja 2017

Popravljen 23. oktobra 2017

Sprejet 26. oktobra 2017 